\title{
COMPUTED TOMOGRAPHY MORPHOMETRIC ANALYSIS OF THE VERTEBRAE C7 AND T1
}

\author{
ANÁLISE MORFOMÉTRICA POR TOMOGRAFIA COMPUTADORIZADA DAS VÉRTEBRAS C7 E T1 \\ ANÁLISIS MORFOMÉTRICO MEDIANTE TOMOGRAFÍA COMPUTARIZADA DE LAS \\ VÉRTEBRAS C7 Y T1
}

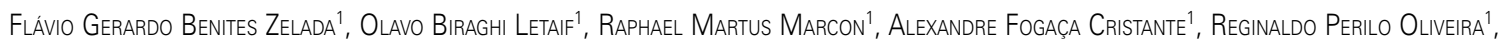
Tarcísio Eloy Pessoa de Barros Filho'

1. Orthopedics and Traumatology Institute of the Hospital das Clínicas da Faculdade de Medicina da Universidade de São Paulo (IOT HC- FMUSP), São Paulo - SP, Brazil.

\begin{abstract}
Objective: The anatomical study of the vertebrae $\mathrm{C} 7$ and $\mathrm{T} 1$ of the cervicothoracic junction aimed to evaluate quantitatively, by axial computerized tomography (CT), the linear and angular dimensions of the anatomical laminae of the vertebrae of the cervicothoracic junction C7 and T1 in adults over 18 years. Methods: We retrospectively analyzed 49 CT of the cervical and thoracic spine (C7 and T1) of individuals over 18 years, of both sexes. We also evaluated the length and thickness of the laminae, as well as spinolaminar angle in axial sections of $\mathrm{C} 7$ and $\mathrm{T} 1$ at the point of least thickness between the inner cortical layers. The variables were correlated with age groups and sex of the individuals. Statistical analysis was performed using the $t$ test and the results were considered significant when $\mathrm{p}<0.05$. Results: After analyzing tomographic measurements of 49 patients, it was found that men had greater laminae thickness than women, both in $\mathrm{C} 7$ and $\mathrm{T} 1$, with $71 \%$ of $\mathrm{C} 7$ laminae and $92 \%$ of $\mathrm{T} 1$ laminae thicker than $5 \mathrm{~mm}$, and $97 \%$ of $\mathrm{C} 7$ laminae and $100 \%$ of $\mathrm{T} 1$ thicker than $4 \mathrm{~mm}$. The mean spinolaminar angle was 56.40 degrees in $\mathrm{C} 7$ and 57.31 degrees in $\mathrm{T} 1$. Conclusion: This study brings important anatomical information about the cervicothoracic junction C7 and T1 in the Brazilian population, showing that fixation of C7 and $\mathrm{T} 1$ with intralaminar screws is anatomically possible.
\end{abstract}

Keywords: Tomography, x-ray computed; Spine; Cervical vertebrae; Thoracic vertebrae.

\section{RESUMO}

Objetivo: O estudo anatômico das vértebras da transição cervicotorácica C7 e T1 teve como objetivo avaliar quantitativamente, por tomografia computadorizada axial (TC), as dimensões anatômicas lineares e angulares de lâminas das vértebras da transição cervicotorácica C7 e T1 em indivíduos adultos maiores de 18 anos. Métodos: Foram analisadas retrospectivamente 49 TC da coluna cervical e torácica (C7 e T1) de indivíduos maiores de 18 anos, de ambos os sexos. Avaliaram-se o comprimento e a espessura das lâminas, bem como o ângulo espinolaminar, em cortes axiais de C7 e T1, no ponto de menor espessura entre as camadas corticais internas. As variáveis estudadas foram correlacionadas com os grupos etários e o sexo dos indivíduos. A análise estatística foi feita pelo teste $t$ e os resultados foram considerados significativos quando $p<0,05$. Resultados: Após análise de medidas tomográficas de 49 pacientes, foi verificado que os homens apresentaram espessura de lâmina maior que as mulheres tanto em C7, quanto em T1, sendo que 71\% das lâminas de C7 e 92\% das lâminas de T1 apresentavam espessura maior que 5 mm e 97\% das lâminas de C7 e $100 \%$ de T1, espessura maior que $4 \mathrm{~mm}$. O ângulo espinolaminar apresentou média de 56,40 graus em C7 e 57,31 graus em T1. Conclusão: $O$ estudo traz informações anatômicas importantes sobre a região da transição cervicotorácica C7 e T1 na população brasileira, mostrando ser possivel anatomicamente, fixação de C7 e $T 1$ com parafuso intralaminar.

Descritores: Tomografia computadorizada por raios x; Coluna vertebral; Vértebras cervicais; Vértebras torácicas.

\section{RESUMEN}

Objetivo: El estudio anatómico de las vértebras de la unión cervicotorácica C7 y T1 tuvo el objetivo de evaluar cuantitativamente mediante tomografía axial computarizada (TAC), las dimensiones anatómicas lineales y angulares de láminas de las vértebras de la unión cervicotorácica C7 y T1 en adultos mayores de 18 años. Métodos: Se analizaron retrospectivamente 49 TAC de la columna cervical y torácica (C7 y T1) de pacientes mayores de 18 años de ambos sexos. Se evaluaron la longitud y el espesor de las láminas, así como el ángulo espinolaminar en secciones axiales de C7 y T1 en el punto de menor espesor entre las capas corticales internas. Las variables se correlacionaron con los grupos de edad y sexo de los individuos. El análisis estadístico se realizó mediante la prueba t y los resultados se consideraron significativos cuando $p<0,05$. Resultados: Después del análisis de las mediciones tomográficas de 49 pacientes, se encontró que los hombres tenían espesor de la lámina mayor que las mujeres, tanto en C7, como en $T 1$, con el $71 \%$ de las láminas C7 y el 92\% de las láminas T1 con espesor mayor que $5 \mathrm{~mm}$, 97\% de C7 y 100\% de T1, mayor que $4 \mathrm{~mm}$ de espesor. El ángulo espinolaminar promedio fue 56,40 grados en C7 y 57,31 grados en T1. Conclusión: Este estudio contiene información anatómica importante sobre la región de la unión cervicotorácica C7 y 11 en la población brasileña, mostrando que es anatómicamente posible la fijación de C7 y $T 1$ con tornillos intralaminares.

Descriptores: Tomografía computarizada por rayos x; Columna vertebral; Vértebras cervicales; Vértebras torácicas. 


\section{INTRODUCTION}

The cervico-thoracic region is an area of transition between the relatively mobile cervical spine and the more rigid thoracic spine. This characteristic means that there is more stress on the commonly used posterior approach fixation implants. ${ }^{1}$ There are various techniques that make fixation of the cervico-thoracic transition possible using the posterior approach. ${ }^{2-4}$ The most common techniques are those that use screws that can be fixed to the lateral masses or to the pedicles; 3,5 however there are limitations, due to the complication rates reported. ${ }^{6,7}$

There is information in the literature about the anatomical characteristics of the spine in studies with cadavers. ${ }^{8-12}$ Panjabi et al. ${ }^{9-11}$ detailed most of the bony structures of the spine, but not those of the laminae. Zindrick et al. ${ }^{12}$ quantified the height and thickness of the laminae, the interlaminar distance, and the epidural space of the thoracic spine in their study of factors that interfere with the penetration of wires into the spinal canal. The authors evaluated the spines of 13 cadavers and reported average values of $18-24 \mathrm{~mm}$ for the laminar height (superior-inferior diameter) and $7-8 \mathrm{~mm}$ for the laminar thickness (anterior-posterior diameter).

Another quantitative anatomical study of the spinal laminae was conducted by Xu et al. ${ }^{8}$ from the perspective of the use of intra-laminar screws. The authors evaluated all the spinal laminae from C2 to L5 in 37 cadavers. However, this study has several limitations that should be highlighted: the laminar length was measured from the middle of the spinous process to the medial margin of the facet joint, which does not correspond to the diameter of the screw, given that it is placed by means of the contralateral lamina; the laminar thickness was measured at its midpoint, with no reference to the thinnest part of the lamina; and the number of cases evaluated was relatively small.

There is no study in the national literature that has quantitatively analyzed the linear and angular parameters of the spine at the cervicothoracic transition in the adult Brazilian population. Thus, the objective of this study was to quantitatively evaluate the linear and angular dimensions of the laminae of $\mathrm{C} 7$ and $\mathrm{T} 1$ in adults older than 18 years of age in order to provide useful information for making decisions about surgery.

\section{MATERIALS AND METHODS}

We retrospectively analyzed 54 computed tomographies performed during routine outpatient and emergency treatment at the complex of the Hospital das Clínicas da Faculdade de Medicina da Universidade de São Paulo (HC FMUSP). This study was approved by the Scientific Commission of the Orthopedics Institute of $\mathrm{HC}$ FMUSP. The Ethics Commission for the Analysis of Research Projects (CAPPesq) waives approvals for this type of study.

Adult patients aged over 18 years of age were selected, and data on the age and the sex of the patients were collected. Cases presenting fractures of the $\mathrm{C} 7$ and $\mathrm{T} 1$ cervicothoracic transition, with or without fixation, or spinal abnormalities, such as deformities, neoplasias in the C7-T1 vertebrae, or rheumatologic diseases, were excluded. Of the 54 tomographies analyzed, five were excluded from the study because one of more of the exclusion criteria applied.

The linear and angular dimensions of the cervicothoracic spinal laminae of C7 and T1 were evaluated in axial CT sections where the lamina was the thinnest. The thickness of laminae C7 and T1 (measurement A) was measured in millimeters $(\mathrm{mm})$. Measurements were obtained at the point of least thickness between the internal cortical layers, as shown in Figure 1. Specific measurements were taken for each side of the lamina. The length of laminae C7 and T1 (measurement B) was measured from the same axial section. The measurements were taken from the cortex opposite the lamina to the limit of the length visible in that section, as we can see in Figure 2. The spine-lamina angle (measurement $\mathrm{C}$ ) was drawn to both sides, with one line on the inside of the laminae of C7 and T1 parallel to the cortices of these laminae and the other line passing through the center of the spinous process and the vertebral body dividing the vertebra into two hemivertebrae. (Figure 3)
The morphometric analysis was performed using the iSite PACS program from Philips Healthcare Informatics ${ }^{\circledR}$.

The statistical analysis was conducted using SPSS 13.0 for Windows. Average, standard deviation, and minimum and maximum values were obtained. The values obtained for each of the variables were correlated with the age groups and the sex of the individuals. Comparisons were made using the student's t test and the results were considered to be significant when $p<0.05$.

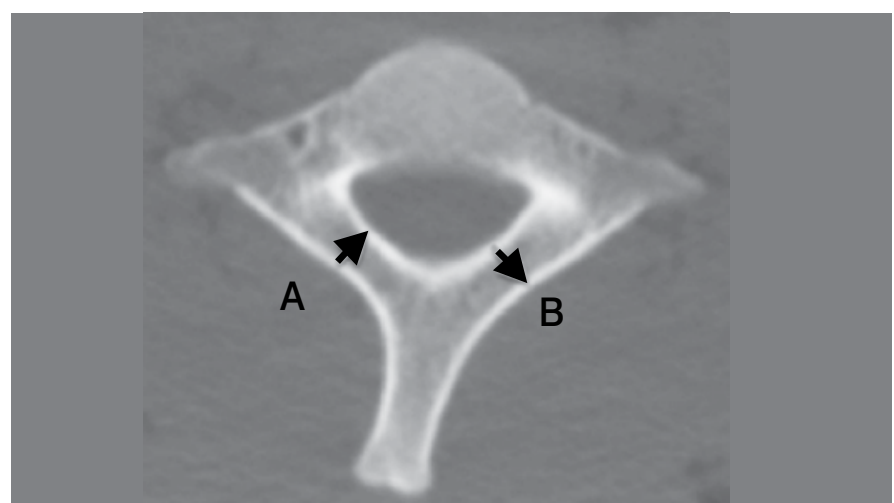

Figure 1. Measurement of thickness.

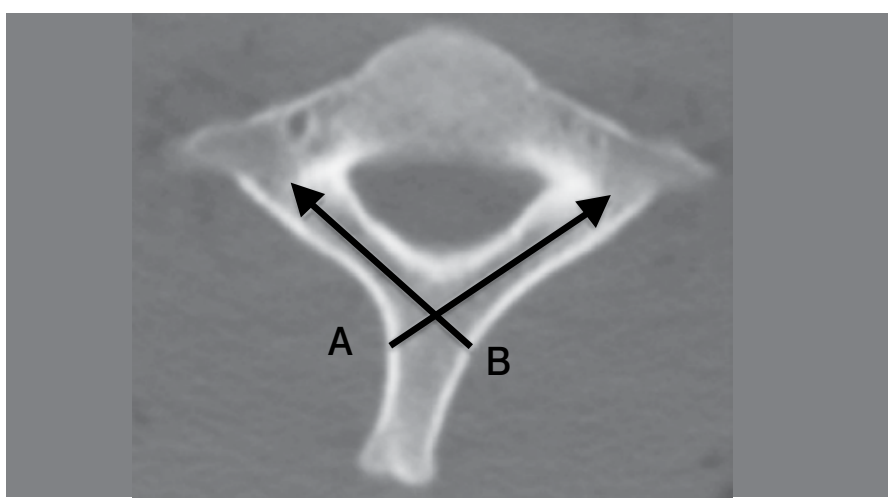

Figure 2. Measurement of the laminar length.

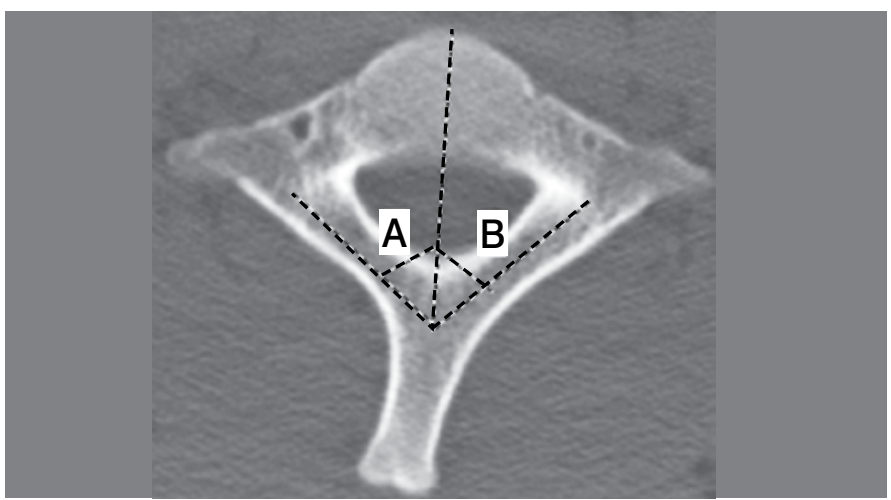

Figure 3. Measurement of the spine-lamina angle (A right, B left).

\section{RESULTS}

Fifty-four tomographies were selected, 5 of which were excluded: 3 due to fractures and 2 because of prior fixation in the region. The remaining 49 tomographies, of 37 men and 12 women, were analyzed. The average patient age was $39.7 \pm 17.16$ years (ranging from 19 to 81 ). The average thickness of the laminae of C7 was $5.78 \pm 1.16 \mathrm{~mm}$ (ranging from 3.5 to 9.2). (Table 1) The thickness measured in the men was greater than that in the women $(5.99 \pm 1.17 \mathrm{~mm}$ vs. $5.13 \pm 0.85 \mathrm{~mm}, \mathrm{p}<0.01)$. Seventy-one percent 
(71\%) of the vertebrae measured had a thickness greater than $5 \mathrm{~mm}$, $97 \%$ greater than $4 \mathrm{~mm}$, and $99 \%$ greater than $3.5 \mathrm{~mm}$. (Figure 4) The average length of the $\mathrm{C} 7$ laminae was $26.03 \pm 3.40 \mathrm{~mm}$ (ranging from 18.2 to $35 \mathrm{~mm})$. The length measured in the men was greater than that in the women $(26.85 \pm 3.37 \mathrm{~mm}$ vs. $23.51 \pm 1.97 \mathrm{p}<0.01)$. The average spine-lamina angle of C7 was greater in the women.

The average thickness of the laminae of $T 1$ was $6.76 \pm 1.04 \mathrm{~mm}$ (ranging from 4.6 to $9.5 \mathrm{~mm}$ ). The thickness of the T1 laminae was greater in the men $(6.97 \pm 1.03$ vs. $6.13 \pm 0.82 \mathrm{~mm}, p<0.01)$. Of the T1 vertebrae analyzed, $92 \%$ had a thickness greater than $5 \mathrm{~mm}$ and $100 \%$ greater than $4 \mathrm{~mm}$. (Figure 5) The average length of the T1 laminae was $25.94 \pm 3.22 \mathrm{~mm}$ (ranging from 19.4 to $33.1 \mathrm{~mm}$ ). There was a statistically significant difference between the sexes, with the greater length measured in the men $(26.61 \pm 3.0993 \mathrm{vs}$. $23.86 \pm 2.74 p<0.01$ ). The measurement of the spine-lamina angle of T1 was greater in the women. (Table 2) There was no difference between the measurements of the right and left sides.

Table 1. Measurements of the C7 vertebrae.

\begin{tabular}{c|c|c|c}
\hline $\mathbf{C 7}$ & $\begin{array}{c}\text { Laminar thickness } \\
\mathbf{( m m )}\end{array}$ & Length $\mathbf{( m m )}$ & $\begin{array}{c}\text { Spine-lamina } \\
\text { angle (degrees) }\end{array}$ \\
\hline All patients & $5.78 \pm 1.16$ & $26.03 \pm 3.40$ & $56.40 \pm 3.51$ \\
\hline Men & $5.99 \pm 1.17$ & $26.85 \pm 3.37$ & $56.12 \pm 3.28$ \\
\hline Women & $5.13 \pm 0.85$ & $23.51 \pm 1.97$ & $57.30 \pm 4.07$ \\
\hline Men vs. Women & $\mathrm{P}<0.01$ & $\mathrm{P}<0.01$ & $\mathrm{P}=0.15$ (NS) \\
\hline
\end{tabular}

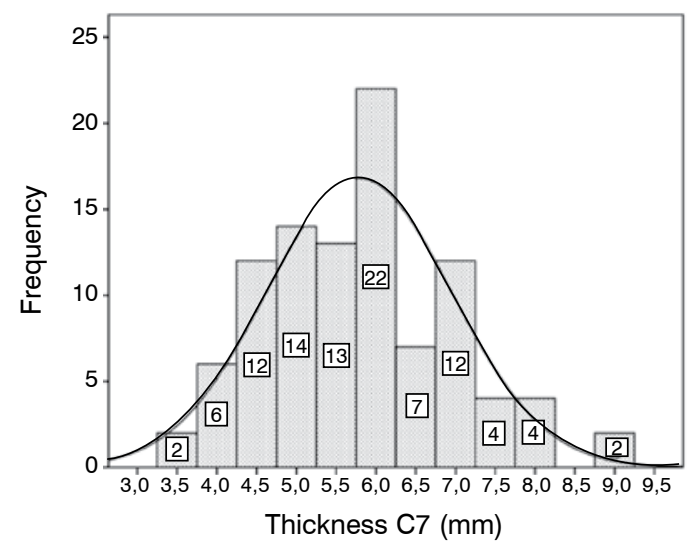

Figure 4. Histogram of the thickness of the laminae of C7.

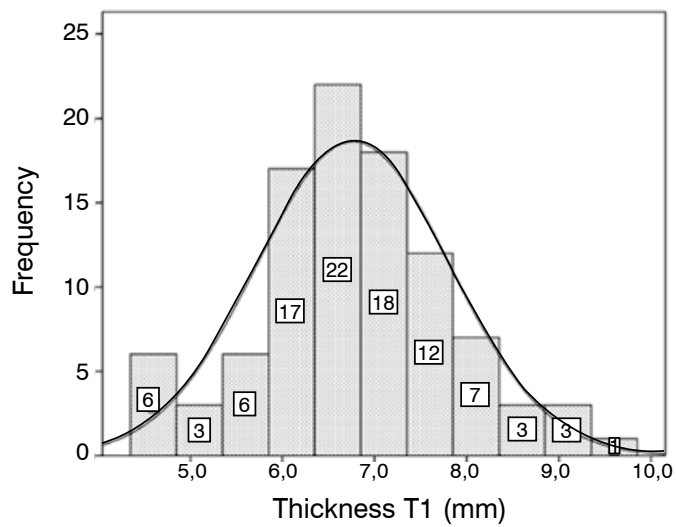

Figure 5. Histogram of the thickness of the laminae of T1.
Table 2. Measurements of the laminae of T1.

\begin{tabular}{c|c|c|c}
\hline T1 & $\begin{array}{c}\text { Laminar } \\
\text { thickness } \\
\mathbf{( m m )}\end{array}$ & Length $(\mathbf{m m})$ & $\begin{array}{c}\text { Spine-lamina } \\
\text { angle (degrees) }\end{array}$ \\
\hline All patients & $6.76 \pm 1.04$ & $25.94 \pm 3.22$ & $57.31 \pm 3.89$ \\
\hline Men & $6.97 \pm 1.03$ & $26.61 \pm 3.09$ & $57.09 \pm 3.82$ \\
\hline Women & $6.13 \pm 0.82$ & $23.86 \pm 2.74$ & $57.99 \pm 4.09$ \\
\hline Men vs. Women & $\mathrm{P}<0.01$ & $\mathrm{P}<0.01$ & $\mathrm{P}=0.32$ (NS) \\
\hline
\end{tabular}

\section{DISCUSSION}

The change from cervical lordosis to thoracic kyphosis in C7, in the region of cervicothoracic transition, results in a load transfer to the posterior aspect. ${ }^{13}$ This creates an increase of stress in this transitional region, which in combination with the anatomical changes in this region, leads to technical difficulties for the passage of screws and motivates the search for fixation options for this region.

Lateral mass screws are more secure and easier to implant. ${ }^{14}$ However, the lateral mass of C7 is frequently not very thick and does not permit the use of long screws. These characteristics make the pullout resistance of lateral mass screws low as compared to transpedicle or translaminar screws. ${ }^{15}$ On the other hand, transpedicle fixation permits the use of longer screws, generally between 25 and $30 \mathrm{~mm}$. Synthesis with transpedicle screws is more stable than fixation in the lateral masses. ${ }^{15}$

The principal challenge in using transpedicle screws in the cervical region is in the technical difficulty of insertion, due to the size of the pedicles and the potentially serious complications, such as lesion of the vertebral arteries, of the spinal cord, and of the nerve roots. ${ }^{5}$ The intraoperative use of radioscopy can assist with the placement of these screw. ${ }^{16}$ However, positioning the radioscope to obtain suitable images may be difficult in some cases. The anatomical variations in the dimensions and morphology of the pedicles of C7 and T1 make surgical techniques based exclusively on bone repairs for the point of screw insertion potentially dangerous. ${ }^{1}$ Even under direct visualization, cortical ruptures were identified in $8-13 \%$ of the patients. . $^{3,4}$

One of the extremely important factors for the correct execution of any surgical procedure is precise knowledge of the anatomy of the region to be operated. In this context, there are no studies in the Brazilian literature that have focused on evaluating the characteristics of the laminae of C7 and T1. Other studies of laminar measurements were conducted by Xu et al., ${ }^{8}$ but because they were conducted before the introduction of intralaminar screws, the measurements were taken differently, making comparison between the studies impossible.

The customary use of intralaminar screws in the C2 lamina for C1-C2 fusion, by means of the technique developed by Wright, ${ }^{17}$ is motivated by the technical difficulties of passing screws into the pars (Magerl) and the pedicle (Harms) and also by the complication rates of these procedures. ${ }^{7}$ However, there are few case reports in the literature with the use of translaminar screws in C7 and T1, the major advantage of which is to avoid vascular lesions, especially when the vertebral artery passes through the transverse foramen of $\mathrm{C} 7$, in addition to its being technically easier to perform. ${ }^{18,19}$

The results obtained show a significant difference between the sexes in the length and width of the laminae, but not in the angulation of the laminae. The thickness of the lamina in C7 was greater than $4 \mathrm{~mm}$ in $97 \%$ and $5 \mathrm{~mm}$ in $71 \%$, which theoretically makes the passage of an intralaminar screw of greater diameter and length than usually used in the lateral mass of C7 (of $3.5 \mathrm{~mm}$ ) possible. In T1, the thickness was greater than $4 \mathrm{~mm}$ in $100 \%$ of the cases and greater than $5 \mathrm{~mm}$ in $92 \%$, which theoretically makes possible the use of a slightly thicker screw in the lamina, avoiding the risk of 
pedicular screw complications in T1. In this context, a new study to evaluate the mechanical resistance of intralaminar implants to stress in the region, performed in cadavers, could be a starting point for the safe use of intralaminar screws in this region of the anatomy.

\section{CONCLUSION}

Significant differences in the measurements of the length and the diameter of the laminae were observed between the men and the women, but no statistical difference was found in the angulation of the laminae. This study provides important anatomical information for a possible alternative method for the fixation of $\mathrm{C} 7$ and $\mathrm{T} 1$ using translaminar screws in the Brazilian population.

All authors declare that there are no potential conflicts of interest regarding this article.

CONTRIBUTIONS OF THE AUTHORS: Each author made significant individual contributions to the development of the manuscript. FGBZ participated in the study design, the collection, analysis, and interpretation of the data, and the critical and intellectual review of the work. OBL participated in the study design, the analysis, and interpretation of the data, and the critical and intellectual review of the work. RMM, AFC, POR, and TEPBF were actively involved in the discussion of the results and made intellectual contributions. All the authors read and approved the final version of the manuscript for publication and were responsible for all aspects of the study. All the authors contributed to the intellectual concept of the study.

\section{REFERENCES}

1. Delamarter RB, Batzdorf U, Bohlmann $\mathrm{HH}$. The C7-T1 junction: problems with diagnosis, visualization, instability, and decompression. Orthop Trans. 1989;13:218.

2. JohnstonTL, Karaikovic EE, Lautenschlager EP, Marcu D. Cervical pedicle screws vs. lateral mass screws: uniplanar fatigue analysis and residual pullout strengths. Spine J. 2006:6(6):667-72.

3. Jones EL, Heller JG, Silcox DH, Hutton WC. Cervical pedicle screws versus lateral mass screws. Anatomic feasibility and biomechanical comparison. Spine (Phila Pa 1976). 1997:22(9):977-82

4. Rhee JM, Kraiwattanapong C, Hutton WC. A comparison of pedicle and lateral mass screw construct stiffnesses at the cervicothoracic junction: a biomechanical study. Spine (Phila Pa 1976). 2005;30(21):E636-40.

5. Albert TJ, Klein GR, Joffe D, Vaccaro AR. Use of cervicothoracic junction pedicle screws for reconstruction of complex cervical spine pathology. Spine (Phila Pa 1976). 1998;23(14):1596-9

6. Liu YJ, Tian W, Liu B, Li Q, Hu L, Li ZY, et al. Comparison of the clinical accuracy of cervical (C2-C7) pedicle screw insertion assisted by fluoroscopy, computed tomography-based navigation, and intraoperative three-dimensional C-arm navigation. Chin Med J (Engl). 2010;123(21):2995-8.

7. Rocha ID, Jorge DMF, Pasqualin T, lutaka AS, Rodrigues MB, Oliveira RP, et al. Tomographic analysis for the placemant of laminar C2 screws. Coluna/Columna. 2008;7(2):230-234

8. Xu R, Burgar A, Ebraheim NA, Yeasting RA. The quantitative anatomy of the laminas of the spine. Spine (Phila Pa 1976). 1999;24(2):107-13.

9. Panjabi MM, Duranceau J, Goel V, OxlandT, Takata K. Cervical human vertebrae. Quantitative three-dimensional anatomy of the middle and lower regions. Spine (Phila Pa 1976). 1991;16(8):861-9.

10. Panjabi MM, Goel V, Oxland T, Takata K, Duranceau J, Krag M, Price M. Human lumbar vertebrae. Quantitative three-dimensional anatomy. Spine (Phila Pa 1976). 1992;17(3):299-306

11. Panjabi MM, Takata K, Goel V, Federico D, Oxland T, Duranceau J, Krag M. Thoracic human vertebrae Quantitative three-dimensional anatomy. Spine (Phila Pa 1976). 1991:16(8):888-901.

12. Zindrick MR, Knight GW, Bunch WH, Miller MC, Butler DM, Lorenz M, et al. Factors influencing the penetration of wires into the neural canal during segmental wiring. J Bone Joint Surg Am. 1989;71(5):742-50

13. Ebraheim NA, Xu R, Knight T, Yeasting RA. Morphometric evaluation of lower cervical pedicle and its projection. Spine (Phila Pa 1976). 1997;22(1):1-6.

14. Pelton MA, Schwartz J, Singh K. Subaxial cervical and cervicothoracic fixation techniques--indications, techniques, and outcomes. Orthop Clin North Am. 2012;43(1):19-28.

15. Hong JT, Qasim M, Espinoza Orías AA, Natarajan RN, An HS. A biomechanical comparison of three different posterior fixation constructs used for c6-c7 cervical spine immobilization: a finite element study. Neurol Med Chir (Tokyo). 2014;54(9):727-35

16. Koktekir E, Ceylan D, Tatarli N, Karabagli H, Recber F, Akdemir G. Accuracy of fluoroscopically-assisted pedicle screw placement: analysis of 1,218 screws in 198 patients. Spine J. 2014;14(8):1702-8.

17. Wright NM. Posterior C2 fixation using bilateral, crossing $C 2$ laminar screws case series and technical note. J Spinal Disord Tech. 2004;17(2):158-62.

18. Koltz MT, Maulucci CM, Sansur CA, Hamilton DK. C7 intralaminar screw placement, an alternative to lateral mass or pedicle fixation for treatment of cervical spondylytic myelopathy, kyphotic deformity, and trauma: A case report and technical note. Surg Neurol Int. 2014:5:4

19. Hong JT, Sung JH, Son BC, Lee SW, Park CK. Significance of laminar screw fixation in the subaxial cervical spine. Spine (Phila Pa 1976). 2008;33(16):1739-43. 